\title{
Örgütsel Adalet ve İş Tatmini: Sağlık Sektöründeki Önemi
}

\section{Organizational Justice and Job Satisfaction: The importance in Health Care Sector}

\author{
Selma SÖYÜK ${ }^{\mathrm{a}}$
}

\begin{abstract}
ÖZ Bir örgütte çalışanların iş yerindeki tüm algılamaları ve tutumları (örgütsel adalet, örgütsel güven, iş tatmini vb.) iş performanslarını önemli ölçüde etkiler. Özellikle çalışanların örgütsel adalet algıları; örgütsel bağlllık, iş tatmini, örgütsel vatandaşlık davranışı, örgütsel güven, işe yabancılaşma gibi pek çok örgütsel sonuca neden olur. Örgüt içindeki çalışanların iş doyumsuzluğu tıpkı örgütsel adalet algısı gibi kişiye ve örgüte zarar verecek olumsuz sonuçlar yaratabilir. Bu nedenle hem örgütsel adalet algısı, hem de iş tatmini yöneticiler tarafindan iyi bilinmeli ve çalışanın iş tatminini artıracak iş ortamı yaratılmaya çalışılmalıdır. İş tatmini kavramı, sonuçlarının taşıdığı bu önem dolayısı ile örgütsel davranış, sosyoloji, sağlık yönetimi, insan kaynakları yönetimi, psikoloji alanlarında en çok araştırma yapılan konuların başında gelmektedir. Özellikle insan emeğinin yoğun olduğu sağlık sektöründe çalışan personelin iş tatminsizliğinin sonuçları doğrudan hastalara yansır. Buna paralel olarak da hasta memnuniyeti düşer ve bu da kuruma ekonomik açıdan zarar verir. İş tatminsizliği ve örgütsel adalet algısının düşük olduğu çalışanlarda iş gücü devri ve devamsızlık oranlarının fazla olduğu yapılan çalışmalarla ortaya konmuştur. Yine iș tatminsizliği sağlık çalışanlarında oldukça sık görülen tükenmișlik sendromuna da neden olması nedeniyle ayrıca önem taşır. Bu derleme çalışmasında her iki konuya dikkat çekmek amaçlanmış ve sağlık sektöründeki önemine değinilmiştir.
\end{abstract}

Anahtar Kelimeler: Örgütsel adalet, iş tatmini, sağlık kurumları yönetimi

\begin{abstract}
The success of individuals in an organization can vary greatly depending on each other and their interaction with management. Individuals' perceptions of the organizational environment and its elements related to this environment (organizational justice, job satisfaction, etc.) may also affect their performance. The sense of organizational justice is an issue that should be emphasized because it is the result of many organizational consequences, especially job satisfaction. Job satisfaction of the employee who is not perceived fairly will be adversely affected. The fact that even an employee in organizations is not happy sometimes can cause all jobs to stop. Since both organizational justice perception and job satisfaction are the causes of many organizational consequences, healthcare institutions must be well known by their managers and an attempt should be made to create a business environment that will increase the employee's job satisfaction. Job satisfaction is one of the most studied topics in organizational behavior, sociology and health management. In case of unfair perception of the employee organization and its manager, it can reduce job performance, productivity, trust, organizational commitment and result in job dissatisfaction. The employee who is not satisfied with his job will reflect this on his business results. As a result, all of these will be reflected in the health institutions and patient satisfaction will be reduced. Employees who are experiencing job dissatisfaction are also over-represented in the labor force. Also, organizational silence, alienation to work and burnout syndrome, which is common in the health sector, are undesirable consequences in organizations as a result of job dissatisfaction. This review explains how to draw attention to both issues and touches on its importance in the health sector.
\end{abstract}

Key words: Organizational justice, job satisfaction, health institutions

\section{Giriș}

Son yıllarda yapılan araştırmalara bakıldığında çalışmaların daha çok bireyler arası etkileşim ve bu etkileşimden kaynaklanan sorunlar/ sonuçları üzerinde olduğu görülmektedir. Değişen iş yaşamı koşulları, yoğun rekabet gibi unsurlarla örgütün baş edebilmesi için bu bireysel ve bireylerarası etkileşimin iyi bilinmesi gereklidir. Artık tüm örgütlerin çalışanlarının etkin ve verimli şekilde çalışmalarına imkân sağlayacak ortamı hazırlamaları zorunlu hale gelmiştir. Çalışanlar örgütlerinin kendilerine verdiği örgütsel desteğe, kendilerine adil davranıp davranılmadığına, kendilerine huzurlu iş ortamı sağlanmasına, örgüte katkılarının önem ve değerinin bilinmesine göre inanış ve tutum

\footnotetext{
Geliş Tarihi/Received:10-08-2018 / Kabul Tarihi/Accepted:20-09-2018

a İ.Ü-Cerrahpaşa Sağlık Bilimleri Fakültesi Sağlık Yönetimi Bölümü,e-mail: ssoyuk@istanbul.edu.tr ORCID: 0000-0001-9822-9417
} 
geliştirirler ve sonuçta bu inanış ve tutumlara göre davranış biçimlerini belirlerler. $\mathrm{Bu}$ tutumların en önemlilerinden biri iş tatminidir. Örgütler, amaç ve hedeflerine iş tatmini yüksek bireyler sayesinde ulaşacaktır. İşgörenlerin örgütsel amaçlar doğrultusunda katkılarını arttıran en önemli faktörlerin iş tatmini ve örgütsel adalet algısının olduğu söylenebilir.

\section{Örgütsel Adalet Kavramı}

Örgütlerde kişiler arası etkileşim ve etkileşime bağlı sonuçların önem kazanmaya başlaması ile birlikte ilk olarak "sosyal adalet" kavramı ortaya atılmıştır. Sosyal adalet konusunda yapılan çalışmalar zamanla örgüt içindeki bireylerarası ilişkilerin sonucunda ortaya çıkan “örgütsel ve kişisel her türlü çıktının, ödül ve cezanın adil dağıtımı anlamına gelen örgütsel adalet (organizational justice)" kavramı geliştirilmiştir (1).

\section{Örgütsel Adaletin Tanım ve Önemi}

Adalet ile ilgili ilk araştırmalar sosyal psikoloji alanında başlamıştır ve zaman içerisinde gelişimini sürdürmüştür. Örgütsel adalet; bireyin iş arkadaşları, üstleri ve kurumla olan ilişkileri açısından algılamalarını içeren bir sosyal sistemdir (2). Greenberg' e göre örgütsel adalet; "iş yerinde adaletin, bireye ve örgüte olan etkilerini ortaya çıkarmaya yarayan terim" dir (3). Daha net bir tanımlama yapılacak olursa; örgütsel adalet, örgüt içinde çalışanların ne kadar adil davranıldığı konusundaki algılarını ve bu algının diğer sonuçları (örgüte bağl1lık, iş tatmini, örgütsel güven, vb.) nasıl etkilediğini içeren bir kavramdır (4).

Örgütsel adalet alg1s1 bireye özgüdür. $\mathrm{Bu}$ alg1, bireyden bireye değiş̧ebildiği gibi ülkeler, toplumlar, medeniyetler ve zamana göre de farklılık gösterebilir (3).

Örgütsel adalet kavramı örgütlerde pek çok süreç ve uygulamalarda ön plana çıkmaktadır. Eleman seçimi, eğitim ve görevlendirme, kariyer planlama, terfi, performans değerlendirme, malzeme ve gereçlerin dağıtımı, ücret, işten çıkarma bunlardan birkaçıdır (5-6).

Adalet kavramı örgütlerde üç ana noktada önem kazanır. Bunlar "sonuçların dağıtımı, dağıtım kararının verilmesi, dağıtım sırasında kullanılan yöntemler ve kişiler arası ilişkiler" şeklinde ifade edilmektedir. Bu üç temel nokta örgütsel adalet türlerini de ortaya koymaktadır (4).

\section{Örgütsel Adaletin Türleri}

Literatürde örgütsel adaletin türleri konusunda farklı ayırımlar yapılmıştır. Ancak çoğu yazar örgütsel adaletin "dağıtım adaleti, prosedür adaleti ve etkileşim adaleti" olmak üzere üçe ayrıldığını ifade etmişlerdir.

Dağıtım Adaleti (Distributive Justice): Dağıtım adalet, çalışanların eline geçen sonuçların adilliğin algılanmasını ifade eden adalet türüdür. Dağıtım adaleti, terfi, ödül ve ceza, ücret gibi unsurların paylaşımını ve çalışanların bu paylaşımların adilliği konusundaki algısını ifade eder $(7,8)$. Dağıtım adaletini kavramı Adams'ın Eşitlik Teorisi sonucunda ortaya çıkmıştır. Çalışanlar kurum içinde kendi ortaya koydukları girdileri (tecrübe, kıdem, eğitim, iş stresi) ve çıtılları (terfi, ödül, maaş) iş arkadaşlarının girdi/çıktıları ile karşılaştırırlar. Karşılaştırma sonucunda girdileriyle aldıkları sonuçlar arasında bir eşitsizlik olduğunu algılarlarsa adaletsizlik duygusu yaşarlar. $\mathrm{Bu}$ algı sonucunda çalışan kendi girdi ve sonuçlarını değiştirmeye çalışacağı gibi iş arkadaşlarına da müdahale yollarına başvurabilir (9-11). Dağıtım adaleti algısında tüm kaynakların adil dağıtımı önemlidir bunun yanında ceza ve ödül dağıtımı da önemli rol oynar (12). Birey dağıtım adaletini düşük algılarsa strese girer ve iş performansı düşer (13).

Prosedür Adaleti (Procedural Justice): Prosedür adaleti; çalışanların prosedür ve sonuçlar konusunda bilgilendirilmeleri ve tüm işlemlerin kişilerarasında eşit uygulanmasıdır. Literatürde prosedür adaleti kavramı yerine işlemsel adalet ya da uygulamaya ilişkin adalet gibi tanımlamaların yapıldığı da görülmektedir. Örgüt içinde alınan kararlarda elemanların da fikirleri ve onayları alındığı zaman prosedür adaleti algısı yükselir (14). Prosedür adaleti tüm karar verme süreçleri, kaynak ve sonuçların dağıtım prosedürlerinin açıklanması ve doğru yönetilmesi, çatışma çözümü yöntem ve süreçlerinden etkilenir. Çalışanların prosedür adaleti algıları, kurum içinde pek çok sonuca neden olabilmektedir (8). Prosedür adaletinde diğer önemli bir nokta ise çalışanların yöneticilerine duydukları güvendir. Yöneticiye güven ile adalet algısı arasında pozitif yönde bir ilişki vardır. Yöneticiye güven duyulan örgütlerde çalışanların prosedürleri ve alınan pek çok kararı sorgulamamadan kabul ettikleri görülmüştür. Ancak yöneticiye güven 
duyulmayan örgütlerde ise prosedür ve kararlar çok fazla incelenir (15).

Etkileşim Adaleti (Interactional Justice): Etkileşim adaleti, prosedürleri uygulayanların çalışanlara gösterdikleri tutum ve davranışlarla ilgilidir. Bu nedenle prosedür adaletine bağlı bir boyut olduğu da söylenmektedir (16). Etkileşim adaletinin insani boyutu önemlidir. Etkileşim adaleti, örgütlerde tüm uygulamalar sırasında kişiler arası davranışların algılanması sonucunda ortaya çıkar (1). Etkileşim adaleti algıs1, haberleşme sürecinden etkilenmektedir. Örgütlerde kişilerarası ilişkilerde nezaket, dürüstlük, saygı unsurları önemlidir (17). Etkileşim adaleti algısı düşük olduğunda çalışanlar bireylere değil yöneticilere karş1 olumsuz tutum sergilerler. Etkileşim adaleti ölçülürken yönetici davranışı sorgulanır ve bireylerden bu yönde karar vermesi istenmektedir.

Etkileşime dayalı olan adaletin bu boyutu pek çok teorisyen tarafindan "bilgilendirmeye dayalı adalet algısı" olarak da isimlendirilmektedir $(18,17)$. Etkileşim adaleti alınan kararların çalışanlara söylenme tarzından etkilenir (9). Gereenberg'e göre, yöneticiler daima astları tarafindan adil olarak algılanmak isterler. Adil olarak algılanmanın bir yolu, bir şeylerin kötü gitmesi esnasında çalışanlara yöneticiler tarafından olayların nedenleri ve sonuçları hakkında açıklama yapılmasıdır (19). Çalışanlar, sonucunda kendilerinin etkileneceği kararlarda, düşünceleri alınırsa, karar olumsuz ve sonucu kötü de olsa bu sonuçlara katlanmakta ve bundan da tatminsizlik duymamaktadırlar.

\section{Örgütsel Adalet Sonuçları}

Örgütsel adalet kavramı ortaya çıkardığı önemli sonuçlardan dolayı farklı disiplinler tarafindan ele alınmıştır $(7,20)$. Örgütsel adalet algısının en önemli sonuçlarından biri örgütsel vatandaşlık davranışlarıdır. Adalet algısının düşük olması işe devamsızlık ve iş gücü devrini etkiler. $\mathrm{Bu}$ da kurumdaki verimlilik ve iş performansını düşürür. Örgütsel adalet saygınlık algısı ve işe bağl1lık üzerinde de önemli rol oynar. Adalet algısı düşük olan çalışanın alınan kararlara tepkileri artar ve yönetime/yöneticiye güven duyguları azalır, bağlılığının azalması ile işe devamsızlık oranı da artar. $\mathrm{Bu}$ olumsuz sonuçlar çalı̧̧anların sağlığını da etkiler. Ayrıca örgütsel adaletin önemli sonuçları arasında örgütsel vatandaşlık karşıtı davranışlar, iş tatmini, işe yabancılaşma sayılabilir. İş tatmini bu faktörler arasında en fazla etkilenen unsurdur $(11,13,21,22)$. Adalet algıs1 çalışma ortamında işbirliğinin gelişmesine yardımcı olur. Çalışanlar arasındaki sosyal bağları güçlendirir.

Çalışanlar, yöneticilerini adil olarak algılarsa iş birliği yaparlar, tüm kararlara katılır ve onlar yokken alınan kararlara destek verirler $(23,24)$. Adalet algısı, çalışanları birbirleri ve örgüt ile bütünleştirir. Adil algılanan örgütlerde belirsizlik durumları da azalır.

Örgütsel adalet algısının sonuçlarının bilinmesi oldukça önemlidir Özetle adalet algısının yüksek olması çalışanlarda pozitif davranış ve tutumlara neden olmaktadır. Yüksek adalet algısı çalışanın iş performansını, verimini arttırır, bu tüm örgütsel sonuçlara hatta müşteri memnuniyetine yansır $(4,7,8,25)$.

\section{İș Tatmini}

Tüm dünyada iş yaşamında insan ön plana çıkmıştır ve insan kaynağına verilen önem artmıştır. Çalışan performansı işinden duyacağ 1 haz ile doğru orantılı olarak artacaktır. Örgütler hedeflerine ancak insan faktörüyle ulaşacaklarını anlamışlardır. Örgütlerin kullandıkları kaynaklar arasında en karmaşık ve değişken olanı insan gücüdür. Çalışanın küçük bir bölümünün bile memnuniyetsizliği bütün kurum faaliyetlerini etkileyebilir.

\section{İş Tatmini Kavramının Tanımı ve Önemi}

İş tatmini, örgütsel olarak 20 yy. da en çok araştırma yapılan kavramlar arasındadır. İş tatmini çeşitli boyutlara sahip çok boyutlu bir yapıdır (26). İş tatmini bireylerin gerek iş yaşamı, gerekse iş dışındaki yaşamı açısından önemli olarak değerlendirilmektedir. İş tatmini modern yönetim anlayışının en önemli faktörlerinden biridir.

Literatürde en yaygın kullanılan iş tatmini tanımının Davis'in tanımı olduğu görülmüş̧ür. $\mathrm{Bu}$ tanıma göre iş tatmini; "kişierin işlerinden duydukları memnuniyet ya da memnuniyetsizlik" tir (27). İş tatmini, çalışanların işin kendisi ve ilgili çevresi hakkındaki bir tutum veya görüşleri, iş rollerine tamamen duygusal bir tepkidir (21). "İş tatmini; bireyin işine, çalışma ortamına, karşılaştığı davranışlara ve aldığ olumlu veya olumsuz duygusal tepkilerdir" (28). İş tatmini kavramı Maslow "un "İnsan İhtiyaçları Hiyerarşisi Kuramı (1954)" ile ilk kez ortaya atılmıştır onu Herzberg "in "Çift 
Faktör Kuramı (1959)" izlemiştir (29). İş tatmini, iş şartlarının ve işten elde edilen sonuçların bireysel değerlendirmesidir (30).

Çalışanların örgüt içinde üretken, verimli, başarılı ve mutlu olmalarını sağlayan en önemli unsurdur. İş tatmini bireyin işinden algıladığı hoşnutluk duygusudur. Genel olarak iş tatmini, sosyolojik ve psikolojik boyutları olan ve bireysel gereksinimler ile kurumsal beklentiler arasındaki bir uzlaşma işlevi olarak tanımlanabilir (31).

Bazı kişilerin diğerlerine göre daha fazla iş tatmini duyması bireysel özelliklerin iş tatminin de önemli rol oynadığ düşüncesini akla getirmiştir. $\mathrm{Bu}$ konuda yapılan bilimsel araştırmalar da bu düşünceyi desteklemiştir. İş tatmininin eğitim, meslek, yaş, kişilik, cinsiyet, zeka ve kültürel çevre gibi bireysel özelliklerden etkilendiği bilimsel araştırmalar sonucunda ortaya konmuştur $(15,32,33)$.

İş tatmini örgüte bağlı nedenlerden de etkilenmektedir. Alınan ücret miktarı, yapılan iş, terfi ve yükselme imkanları, iş ortamı ve koşulları, güvenlik önlemleri, yönetici davranışları, iş arkadaşları ile olan ilişki ve etkileşim biçimi iş tatminini etkileyen örgütsel ve çevresel faktörler arasında (15,34). Bu faktörler bireysel değildir. Analiz edilebilmekte ve ölçülebilmektedirler.

\section{İş Tatminsizliğinin Sonuçları}

İş tatmini bireylerin gerek iş yaşamı, gerekse iş dışındaki yaşamı açısından önemli olarak değerlendirilmektedir. İş tatmini yüksek olan kişi özel yaşamında da daha iyimser ve mutlu olmaktadır. İş tatminsizliği hem örgütsel hem de bireysel pek çok olumsuz sonuca neden olabilmektedir (35).

İş tatmininin düşük olması örgüt içinde pek çok durumu olumsuz etkiler. İş tatmini düşük olduğunda örgütsel başarı, örgütsel bağl1lık, iş performansı ve verimlilik düşer, devamsızlık, işgücü devri ve işte hata oranı artar, işe yabancılaşma, tükenmişlik sendromu ve kişilik bozuklukları görülür. Yine iş tatminsizliği durumunda çalışan iş saatlerinde özel işleri ile uğraşır, uzun uzun dinlenme arası verir, iş yapar gibi görünür ama yapmaz, sürekli gereksiz sohbet ederek iş arkadaşlarını meşgul eder, sürekli ve kasitlı olarak yönetim kademelerini eleştirir ve tartışma çıkarır, iş arkadaşlarına saldırgan davranış ve tutum sergiler. İş tatminsizliği yaşayan birey, ister istemez kurumuna karşı olumsuz tepkiler içine girmektedir $(36,37)$.
İş tatmininin davranışlara, fiziksel ve ruhsal sağglığa doğrudan etkileri bulunmaktadır. Beklentilerin karşılanamaması sonucunda ortaya çıkan iş tatminsizliği çalışan sağlığını olumsuz etkilemektedir. $\mathrm{Bu}$ durumda kişinin psikolojisi bozulmakta ve istenmeyen davranışlara neden olabilmektedir. İş tatminsizliği psikosomatik rahatsızlıklara da neden ola-bilmekte ve sigara-alkol gibi kötü alışkanlıklara da neden olabilmektedir. İş tatminsizliğinin yukarıdaki olumsuz sonuçlarının yanı sıra çalışan üzerinde psikolojik sonuçları da bulunmaktadır. Tatminsiz birey işe gitmede çok isteksiz davranmaktadır $(15,38)$. Çalışanın iş doyumu organizasyonun performansını da belirlemektedir. Düşük iş doyumu olan birey yeni iş arayacaktır. Dolayısıyla iş doyumu örgütsel performansı etkilemektedir (39).

\section{Örgütsel Adalet ve İş Tatmini}

Dikkatli bakıldığında iş tatmini ve örgütsel adalet algisina neden olan unsurlar hemen hemen aynı unsurlardır. İş tatminini etkileyen unsurlara bakıldığında, adil ücret dağıtımı, kararlara katılım, bilgilendirme, adil terfi, iş arkadaşları ile iyi ilişkiler, yönetici davranışları sayılmıştır. Bu etmenler örgütsel adalet algısını etkileyen etmenlerle aynidır. Dolayısıyla adalet algısı olumlu olan iş görenin tatmin olması da doğal bir süreçtir.

Literatüre bakıldığında, yapılan bilimsel çalışmalar sonucunda örgütsel adalet algısı ile iş tatmini arasında pozitif yönde bir ilişsi olduğu görülmüştür. Çalışmaların çoğunda adalet algısının yüksek olduğu örgütlerde iş tatmini, örgütsel güven, örgütsel bağlllık, yüksek iş performansı gibi pek olumlu sonuca rastlandığ 1 ifade edilmiştir. Son yıllarda örgütsel adalet ve iş tatmini ilişkisini inceleyen pek çok araştırma yapılmıştır. Bu araştırmaların bazıları; Yuan ve arkadaşları (2016), Iqbal (2013), Usmani ve Jamal (2013), Dugguh ve Ayaga (2014), Addai ve arkadaşları (2018), Karavardar (2015), Yıldız, 2014, Altaş ve Çekmecelioğlu (2015), Emre ve Ağca (2018), Yürür, (2005), Keklik ve Us (2013), Koyutürk, (2015), Söyük (2007) tarafından yapılmıştır. Çalışmalarda iş tatmini ile örgütsel adalet algısı arasında pozitif yönde ilişki olduğunu bulmuşlardır (7-8,10,15-38,40-43).

Palamutçuoğlu ve arkadaşları 2016 yılında 64 yerli ve yabancı çalışmayı içeren bir metaanaliz yapmışlar ve metaanaliz sonucunda örgütsel adalet algısının iş tatminin de etkili olduğu sonucuna ulaşmışlardır (44). Kişilerin 
adalet algıları çok düşük olursa, doğrudan iş performanslarını azaltma yerine örgütsel bağlılıklarını ve grup arkadaşlarına olan bağl11ıklarını azaltma yoluna giderler. Bunun sonucunda da iş tatminini düşer $(15,19)$.

Ücret hem iş tatmininde hem de dağıtım adaleti algısında etkili olmaktadır. Yine iş tatmininde önemli rol oynayan herkese eşit yükselme imkanının sağlanması, karar alımında çalışanların fikirlerinin sorulması prosedür adaleti algısında da önemli rol oynar. Kurum içi iyi ilişkiler, çalışanları ilgilendiren konularda açıklama yapılması etkileşim adaleti algısı ve iş tatmininde oldukça etkilidir. Ücret örgütsel adalet algısı ve iş tatminsizliğinin önemli belirleyicileri arasında gelmektedir. İş tatminini etkileyen unsurlara bakıldığında bunlar arasında ücret önemli bir yer tutmaktadır. Çalışan ücretin yanı sıra prim dağıtımı, izin dağıtımı, terfi kararları gibi uygulamalarda da eşitlik arar ve bu eşitliği bulamazsa tatminsizlik yaşar.

Kariyer taahhüdü ve örgütsel adalet çalışanın iş tatminini önemli ölçüde etkileyebilir. Prosedür adaleti algıs1 pek çok örgütsel sonuca neden olur (45). Tüm insan kaynakları fonksiyonlarının uygulanmasında (personel seçimi, eğitim, performans değerleme, ücret vb.) adil davranılması iş tatminin olumlu yönde etkiler. Örneğin hizmet içi eğitim uygulamalarında, eğitime katılacakların hangi kriterlere göre seçildiğinin açık bir şekilde anlatılmas1 veya terfi durumunda neden $o$ kişilerin seçildiğinin çalışana açıklanması, çalışanın etkileşim adaleti algısı ve bunun sonucunda iş tatmini algısında rol oynayacaktır.

\section{Sağlık Kurumlarında Örgütsel Adalet Ve İş Tatmininin Önemi}

Bir sağlık kurumunun başarısı çalışanlarını kurumsal amaçlar doğrultusunda istekli ve yüksek motivasyonla harekete geçirmesine bağlıdır. Kurum ne kadar gelişmiş teknolojiye sahip olursa olsun bu teknolojiyi kullanan insan kaynaklarını etkileyerek istekli biçimde harekete geçirmedikçe amaçlarını gerçekleştiremez. Sağlık kurumlarında hizmet sunumunun temel belirleyicisi olan personel, verilen hizmetin kalitesini de büyük ölçüde belirlemektedir. Bu nedenle çalışan memnuniyetinin önemini hiçbir kurum göz ard1 edemez (37).

Sağlık sektörü yoğun stres yaşayan hasta bireye hizmet vermenin yanı sira, bu sektörde çalışanların iş yaşamlarında sık sık stres yaratan olaylarla karşı karşıya kalmaları nedeniyle, diğer sektörlerden farklılık göstermektedir. Sağlık sektöründe hata ve yanılgıya hoşgörü gösterilememektedir. Çünkü hata ve yanılg1 insan hayatına mal olabilmektedir. Sağlık çalışanlarının iş tatminlerinin yüksek olması hasta memnuniyetini de etkiler. Özellikle hastanelerde çalışan sağlık personeli işlerin acil ve ertelenemez olması nedeni ile hızlı karar vermek zorundadırlar. $\mathrm{Bu}$ nedenle sağlik yöneticileri adil yönetimin ve iş tatmininin önemini çok iyi bilmeli ve çalışanlarını nelerin tatmin edeceğinin yollarını aramalıdırlar. Hastanelerde, iş analizleri, iş tanımları, eğitim ve yasal alanlardaki düzenlemeler yetersiz kalmaktadır. Pek çok uygulamanın kimin tarafından yapılacağı kesin değildir. Bu da rol çatışmalarına neden olabilmektedir. Ayrıca, malzeme ve personel eksikliği, çalışma ortamının yetersizliği gibi olumsuz koşullar çalışan tatminini olumsuz yönde etkilemektedir. Birçok çalışma, hemşirelerin işten ayrılma niyetlerinin temel göstergesi olarak iş tatminsizliğini işaret etmektedir. İşten ayrılma niyeti, hemşirelerin işten gerçek olarak ayrılmalarını tahmin eden temel bir göstergedir (46). Topluma sağlık hizmeti sunarken temel amaç, kaliteli ve doğru hizmet sunmaktır. Bu amaç iyi eğitilmiş ve işini doğru yapan sağlik çalışanlarının yüksek örgütsel adalet ve iş tatmini hissetmeleri ile mümkün olacaktır. Sağlık sektöründe yapılan bilimsel çalışmalara bakıldığında; çalışanların iş tatminsizliklerinin her geçen gün arttığı görülebilir.

Sağlık sektöründeki tüm gelişme ve problemler çalışanları olduğu hastaları ve hasta yakınlarını da etkiler. Hasta memnuniyetinin sağlanması için öncelikle sağlık çalışanlarının işinden memnun olmalarının sağlanması önemlidir (47). Hastanelerde zaten iş yükü çok fazladır ve çalışanlar olumsuz duygular yaşamaktadır. İş yükü fazlalığına bir de adaletsiz dağılımın yapılması çalışanların dağıtım adaleti algilarını kötü etkilemekte ve bu durum çalışanın performansında da etkili olmaktadır. Hastanelerde çok sayıda farklı meslek grupları bulunmaktadır. Bu meslek gruplarının kendi aralarında da sorunlar yaşanabilmektedir. $\mathrm{Bu}$ nedenle hastanelerde iyi bir haberleşme sisteminin kurulmas1, birlikte toplantılar yapılarak kararlar alınırken çalışanın fikrinin alınması etkileşim adaleti algısı ve iş tatmininin yükselmesinde etkili olmaktadır. 


\section{Sonuç}

Çalışan personelin psikolojik durumu, tutumları, alg1 ve inanışları onların tüm iş gününü etkileyebilir. Bir personelin bile iş doyumsuzluğu örgütteki tüm sonuçların olumsuz olmasını etkileyebilir. Personel, yöneticilerin ve iş arkadaşlarının tutum ve davranışlarına, ödül ve cezanın dağıtımına, karar alma süreçlerinde kendi fikirlerinin alınmasına, örgütteki bireylerarası ilişkilere bakarak tutum ve davranış geliştirir. $\mathrm{Bu}$ tutumların içinde en önemlisi ve pek çok örgütsel sonuca neden olanı iş tatminidir. Yöneticilerin kendisine ve fikirlerine değer verdiğini düşünen, o kurumda örgütsel adaletin olduğuna inanan personelin iş tatmini de yüksek olacaktır. Pek çok farklı meslek grubunun (44 meslek) bir arada çalıştığı ve her bir sağlık çalışanının çıktısının bir diğerinin girdisi olduğu sağlık sektöründe her bir çalışanın tutum ve davranışı diğer çalışanları da önemli ölçüde etkiler.

Örgütler, rekabet avantajını koruyabilmek için iş tatmini yüksek ve işlerini iyi yapan bireyler ile çalışmak isterler. Sağlık sektöründeki hızlı değişimlere ayak uydurabilecek iş tatmini yüksek çalışanlara örgütlerin her zaman ihtiyacı vardır. Örgütsel adalet iş tatminini etkileyen en önemli unsurlardan biri olmas1 nedeniyle konuya dikkat çekilmeli ve yapılan araştırmaların sayıları arttırılmalıdır.

\section{Kaynaklar}

1- Cohen-Charash Y C, Spector P E. The role of justice in organizations: A meta analysis. Organizational Behaviour and Human Decision Processes. 2001;86(2):278-321.

2- Beugre C D, Baron R A. Perceptions of systemic justice: The effects of distburitive, procedural and interactional justice. Journal of Aplied Psychology. 2001;31(2):324-338.

3- Greenberg J. Setting the justice agenda: seven unanswered questions about "what, why, and how", Journal of Vacotional Behavior. 2001, 58:210-219.

4- Söyük S. Örgütsel adalet [Organizational Justice]. Sağlıkla Dergisi [Health Journal]. 2013; 34-35.

5- Gürbüz S, Mert TíS. Örgütsel adalet ölçeğinin geçerlik ve güvenirlik uygulaması: kamuda görgül bir çalışma [The validity and reliability of the organizational justice scale: a pragmatic study in the public]. Amme İdaresi Dergisi
[Amme İdaresi Journal ].2009;42(3):117139.

6- İyigün NÖ. Örgütsel adalet: Kuramsal bir yaklaşım [Organizational justice: a theoretical approach]. İstanbul Ticaret Üniversitesi Sosyal Bilimler Dergisi [Istanbul Commerce University Journal of Social Sciences].2012; 11(21): 49-64.

7- Addai P, Kyeremeh E, Abdulai W, Sarfod J O. Organizational justice and job satisfaction as predictors of turnover intentions among teachers in the Offinso South District of Ghana. European Journal of Contemporary Education.2018; 7(2):234-243.

8- Usmani S, Jamal S. Impact of distributive justice, procedural justice, interactional justice, temporal justice, spatial justice on job satisfaction of banking employees. Review o f Integrative Business \& Economics Research. 2016;2(1):351-383.

9- Moorman R H. Relationship between organizational justice and organizational citizenship behaviors: Do fairness perceptions influence employee citizenship? Journal of Applied Psychology.1991;76(6):845-855.

10- Iqbal K. Determinants of organizational justice andvits impact on job satisfaction. A Pakistan based survey. International Review o f Management and Business Research.2013; 2(1):48-56.

11- Cropanzano R, Bowen D E, Gilliland S W. The management of organizational justice. Academy of Management Perspectives. 2007;21(4):34-48.

12- Skarlicki DP, Folger R. HRM special issue: Fairness and Human Resources Management. Human Resource Management Review.2003;13:1-5.

13- Sia LA, Tan TA. The influence of organizational justice on job satisfaction in a hotel setting. DLSU Business \& Economics Review.2016;26(1):17-29.

14- Greenberg J, Baron RA. Behavior in Organizations. USA: Prentice Hall Inc. 2000;340-345.

15- Söyük S. (2007). Örgütsel Adaletin İş Tatmini Üzerine Etkisi Ve İstanbul İlindeki Özel Hastanelerde Çalışan Hemşirelere Yönelik Bir Çalışma, Doktora Tezi, İstanbul:İstanbul Üniversitesi Sosyal Bilimler Enstitüsü. 2007.

16- Ramamoorthy N, Flood PC. Gender and employee attitudes: The role of 
organizational justice perceptions. British Journal of Management. 2004;5:247-258.

17- Yürür S. Ödüllendirme Sistemleri İle Örgütsel Adalet Arasındaki İlişkinin Analizi ve Bir Uygulama, Doktora Tezi, Bursa: Uludağ Üniversitesi Sosyal Bilimler Enstitüsü. 2005.

18- Karavardar G. Örgütsel adaletin iş tatmini, örgütsel bağlılık ve işten ayrılma niyeti üzerindeki etkisi [The effect of organizational justice on job satisfaction, organizational commitment, and intent to leave work]. Uluslararası Yönetim İktisat ve İşletme Dergisi [International Management Economics and Business Review].2015;11(26):139-150.

19- Greenberg J. Stres fairness to fare stres: Managing workplace stres by promoting organizational justice. Organizational Dynamics. 2004;33(4):352-365.

20- Adusei H, Sarfo JO, Manukure P, Cudjoe J. If I should stop teaching now, where will I go? Turnover intentions among high school teachers in Ghana. European Journal of Contemporary Education. 2016;17(3): 263271.

21- Yuan G, Jiab L, Zhaoc J. Organizational identification moderates the impact of organizational justice on job satisfaction. Work. 2016;54(1):189-195.

22- Begley T M, Lee C, Hui C. Organizational level as a moderator of the relationship between justice perceptions and workrelated reactions. Journal of Organizational Behavior. 2006;26:705-721.

23- Bos K Van Den. Assimilation and contrast in organizational justice: The role of primed mindsets in the psychology of the fair process effect. Organizational Behaviour And Human Decision Processes. 2002;89:866-880.

24- Cropanzano R, Thomas A W. Procedural justice and organizational staffing: a tale of two paradigms. Human Resource Management Review. 2003;13:187-211.

25- Anderson DM, Shinew K J. Gender equity in the contex of organizational justice: a closer look at a reoccuring 1ssue in the field. Journal of Leusire Research. 2003;35(2):216-232.

26- Sharma P. Organizational culture as a predictor of job satisfaction: The role of age and gender. Journal of Contemporary Management. 2017;22(1):35-48.
27- Davis K. İşletmelerde Örgütsel Davranış [Organizational Behavior in Businesses]. Çeviren: K. Tosun, İstanbul: İstanbul Üniversitesi İşletme Fakültesi Yayınları. 1998:45-47.

28- Toker B. Demografik değişkenlerin iş tatminine etkileri: İzmir'deki beş ve dört yıldızlı otellere yönelik bir uygulama [The effects of demographic variables on job satisfaction: An application for five and four star hotels in İzmir]. Doğuş Üniversitesi Dergisi [Dogus University Journal] .2007;8(1):92-107.

29- Bakan İ, Büyükbeşe T. Örgütsel iletişim ile iş tatmini unsurları arasındaki ilişkiler: akademik örgütler için bir alan araştırması [Relations between organizational communication and job satisfaction elements: a field research for academic organizations]. Akdeniz Üniversitesi İktisadi ve İdari Bilimler Fakültesi Dergisi [Akdeniz University Faculty of Economics and Administrative Sciences Journal]. 2004; 7:1-30.

30- Altaş SS, Çekmecelioğlu HG. Örgütsel adalet algısının iş tatmini, örgütsel bağlılık ve iş performansı üzerindeki etkileri: Okul öncesi öğretmenleri üzerinde bir araştırma [The effects of organizational justice perception on job satisfaction, organizational commitment and job performance: A survey on preschool teachers]. İktisadi ve İdari Bilimler Dergisi [Journal of Economics and Administrative Sciences] 2015;29(3):421-438.

31- Haris EG, Artis AB, Walters JH, Licata JW. Role stressors, servis worker job resourcefulness and job outcomes: an empirical analysis. Journal of Business Research. 2006;59(4):407-415.

32- Seo Y, Ko J, Price J L. The Determinants of job satisfaction among hospital nurses: A model estimation in Korea. International Journal of Nursing Studies.2004;41:437446.

33- Uyargil C. İş Tatmini ve Bireysel Özellikler [Job Satisfaction and Individual Characteristics]. İstanbul:İstanbul Üniversitesi İşletme Fakültesi Yayınları [İstanbul University Business Administration Publications]. 1998:22-23.

34- Tzeng HM. Relationship of nurses assessment of organizational culture, job satisfaction and patient satisfaction with 
nursing care. International Journal of Nursing Studies. 2002;39:280-296.

35- Eun KCC, Hyun WJ. Employee job satisfaction and customer-oriented behavior: A study of frontline employees in the foodservice industry. Journal of Human Resources in Hospitality \& Tourism. 2017;6 (3):235-251.

36- Bowling NA, Beehr TA, Lepisto LR. Beyond job satisfaction: a five year prospective analysis of the dispositional approach to work attitudes. Journal of Vocational Behavior. 2006;69:315-330.

37- Söyük S. Sağl1k sektöründe iş tatmini [Job satisfaction in the health sector]. Hastane Dergisi [Hospital Journal]. 2012;13(74):9495.

38- Koyutürk A. Sağlık Çalışanlarında Örgütsel Adalet Ve İş Doyumu Bir Kamu Hastanesi Örneği. Yüksek Lisans Tezi. İstanbul:Okan Üniversitesi Sağlık Bilimleri Enstitüsü. 2015

39- Yen CH, Hsie, TY. A Study on the management styles and job satisfaction of employees at Taiwan's architectural firms. International Journal of Organizational Innovation. 2017;10(1):185-204.

40- Dugguh SI, Ayaga D. Job satisfaction theories:Traceability to employee performance in organizations. IOSR Journal of Business and Management 2014;16(5):11-18.

41- Yıldız S. Örgütsel adaletin örgütsel vatandaşlık davranışına etkisinde iş tatmininin aracı rolü [The role of organizational justice as an intermediary of job satisfaction in influencing organizational citizenship behavior]. Ege Akademik Bakış [Aegean Academic Overview].2014;14(2):199-210.

42- Emre Ş S, Ağca A. Örgütsel adaletin muhasebecilerin iş memnuniyeti üzerine etkisi: Kütahya örneği [The effect of organizational justice on job satisfaction of accountants: Kütahya example]. Muhasebe ve Finansman Dergisi [Journal of Accounting and Finance]. 2018:27-45.

43- Keklik B, Us N. Örgütsel adalet algılamalarının iş tatminine etkisi: hastane çalışanları üzerinde bir araştırma [The impact of perceptions of organizational justice on job satisfaction: a survey of hospital staff] Süleyman Demirel Üniversitesi İktisadi ve İdari Bilimler Fakültesi Dergisi [Süleyman Demirel
University Faculty of Economics and Administrative Sciences Journal].2013; 8(2):143-161.

44- Palamutçuoğlu BT, Çavuşoğlu S, Palamutçuoğlu A. Örgütsel adalet ile iş tatmini arasındaki ilişkiye meta analitik (meta analitical) bir yaklaşım [A metaanalytical approach to the relationship between organizational justice and job satisfaction]. Uluslararası Alanya İşletme Fakültesi Dergisi [International Alanya Business Administration Journal]. 2016;8(2):203-216.

45- Mazerolle L, Antrobus E, Bennett S, Tyler $T$ R. Shaping citizen perceptions of police legitimacy: Arandomized field trial of procedural justice. Criminology 2013;51(1):33-63.

46- Atencio B L, Cohen J, Gorenberg B. Nurse retention: Is it worth it? Nurse Econ. 2003;2(6):265- 292.

47- Çarıçıı İ, Oksay A. Doktorlar ve hemşireler aynı ekipte farklı tutumlar [Doctors and nurses have different attitudes towards the same team]. Modern Hastane Yönetimi Dergisi [Modern Hospital Management Review]. 2006;10(1):28-40. 